\title{
OSS を用いた数值シミュレーションからの音場合成手法に関する検討 METHODS FOR SYNTHESIZING SOUND FIELDS FROM NUMERICAL SIMULATION
USING ORTHOSTEREOPHONIC SYSTEM (OSS)
}

\author{
渡辺充敏*，木村 翔**，坪井政義***，平野 滋**** \\ Mitsutoshi WATANABE, Sho KIMURA, Masayoshi TSUBOI \\ and Shigeru HIRANO
}

\begin{abstract}
The authors examined adequate solid angle partitioning methods and simple methods to predict the time from the reflection of sound in rooms until diffusion is attained in order to apply reverberation addition methods taking the reflection time structure previously proposed by authors into consideration to numerical simulation. We furthermore pointed out the effectiveness of reverberation addition methods by means of comparative hearing tests using sound fields synthesized from impulse response of reverberation added to early reflections from numerical simulation and actually measured impulse response.
\end{abstract}

\section{Keywords : OSS, Synthetic sound field, Head related transfer function, Reverberation addtion method}

O S S 、合成音場、頭部伝達関数、残響音付加手法

\section{1.はじめに}

図面段階のホールの音を数值シミュレーション結果から合成し、 個々の音響物理指標値等からは把握しにくい音場の諸特性について聴 感上の検討を加える音場合成システムは、有効な音響設計支援技術の 一つとして利用されている1)。

三次元的な㧪がりを持つ音場を合成するためには、数值シミュレー ションにおいて、受音点を中心とした空間を有限な範囲の立体角で分 割し、分割された立体角に対応する方向ごとのインパルス応答を算出 する必要がある。この際、立体角の分割を細かくすれば、より細かい 方向情報を受聴者に提示できると考えられるが、必要以上に細かい分 割は、数值シミュレーションの負荷となり、計算時間の增大につなが るため好ましくない。音場合成システムを音響設計の際に生ずる試行 錯誤に迅速に対応するシステムとするには、方向情報を扱う際の立体 角の分割は、実音場と聴感上の差が生じない範囲内で荒く分割するの が望ましい。

実音場と聴感上の差が生じないように立体角を分割する方法とし て、人の方向知覚能力に基づく方法が考えられる。単一音源による音 の方向弁別限については、多くの測定が試みられている2゙か、数值 シミュレーション時の立体角の分割のために必要となる、受音点を中 心とした上半球に渡る方向弁別限の測定結果は見あたらない。
複数の音源が存在する実音場を想定して、飯田らは、見かけの音源 の幅の変化と両耳相関度の関係に着目し、水平方向に対する立体角の 分割方法を検討している ${ }^{3)}$ が、両耳相関度に基づく場合、正中面にお ける両耳相関度は等しくなるため、正中面の仰角方向を分割すること は出来ない。

筆者らは、これまで音響設計支援システムの一部として、O S S 4) を用いた再生方法による音場合成システムを開発してきた。現在、波 面積分法 ${ }^{5)}$ と呼称する波動性を考虑した数値シミュレーション手法を 用いて、方向別のインパルス応答から音場合成に必要な両耳における インパルス応答を算出しているが、立体角の分割を等立体角として分 割していたため、受聴者の方向知覚能力を考虑した合理的な分割では なかった。

また筆者らは、インパルス応答算出に要する計算時間短縮のため、 実測のインパルス応答を用いた場合の、反射音時間满造を考虑した残 響音付加手法について新たな提案を行い、赛測音場との比較聴感実験 を通してその有効性を示すことができた6)。しかしこの場合、初期反 射音に残響音を付加する直接音からの時間は、実測の短時間指向搪散 度の時間変化 ${ }^{7)}$ を手掛かりとしており、提案した残響音付加手法を数 值シミュレーションからの音場合成に適用するには、音場が拡散状態 に到達したと見なされる時閒を予測し、残響音を付加する時間を明確
* 大林組技術研究所 副主任研究員 ·博士 (工学)

** 日本大学理_工学部 教授.工博

*** 大林組技術研究所 主任研究員 ·博士 (工学:

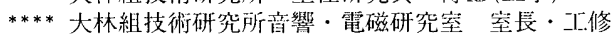

Deputy Chief Research Engineer, Obayashi Corp. Tech. Res. Inst., Dr. Eng.

Prof., College of Science and Technology Nihon Univ., Dr. Eng.

Chief Research Engineer, Obayashi Corp. Tech. Res. Inst., Dr. Eng.

Manager of Acoustic \& Electromagnetic Eng. Dept., Obayashi Corp. Tech. Res. Inst., M. Eng. 
にするとともに、実測のインパルス応答を用いて検討してきた残響音 付加手法が数值シミュレーションのインパルス応答に対しても有効で あるかを聴感実験を通して検討する必要性があると考えられる。

そこで本論文では、OSS 等のトランスオーラル系の再生手法を用い た音場合成システムにおいて、両耳でのインパルス応答の算出に必要 な頭部伝達関数を数值シミュレーションへ組み込むために、方向知覚 能力に基づく立体角の合理的な分割方法について検討している。

また、数值シミュレーションによる初期反射音に残響音を付加する 時間を算定するため、室内が拡散状態に到達するまでの時間の簡易的 予測手法について検討している。

さらに、数値シミュレーションによる初期反射音に反射音時間構造 を考虑した残響音を付加して作成したインパルス応答からの合成音場 と実測のインパルス応答からの音場を用いた一対比較聴感実験から、 提案した残響音付加手法の数值シミュレーションへの適用の有効性に ついて検討している。

\section{2. 立体角の分割}

被験者を中心とした上半球方向からの単一音源による方向弁別限の 測定結果功方向弁別能力の全体的な傾向を捉え、これとみかけの 音源の幅を手挂かりとした複数音源による方向弁別限の測定結果を合 わせて検討し、数値シミュレーションに頭部伝達関数を組み込むため の立体角の分割方法を決定することにした。

\section{1 単一音源による方向弁別限}

実験は無響室内で行った。上半球全体に渡る方向弁別限を測定する ために、図 1 に示す 7 個のスピーカを、それぞれ 4.4 度の角度をつ けて取り付けたスピーカアレイを上下方向に回転するプームに取り付 け、任意の角度に固定できる装置を用いた。仰角方向の変化はブーム を上下に回転させることにより、水平方向の変化はスピーカアレイの 焦点に位置する被験者自身を回転させることにより行った。

試験用信号にはホワイトノイズを用い、実験は適応法によった。ス ピーカアレイ中心のスピーカを基㴗方向とし、中央の基淮スピーカか ら 1.2 秒間ホワイトノイズを提示し、1秒間の休止時間をおいて、比 較する他のスピーカから同様に 1.2 秒間ホワイトノイズを提示する。 基準スピーカと比較スピーカからの提示を一対とし、被験者が「方向 の違いが分からないとと判定したときは、基漸スピーカに対する比較 スピーカの変化角度を増加させ、「分かる」と判定したときは堿少さ せる。これを繰り返し、3回連続して判定が入れ替わっだ角度の中間 をもって方向弁別限とした。なお、ホワイトノイズ出力時の被験者頭 部中心位置におけるスピーカアレイの周波数特性は、 $200 \mathrm{~Hz} \sim 10 \mathrm{kHz}$ において $5 \mathrm{~dB}$ に収まっている。

基準スピーカに対する比較スピー力の変化方向は、水平および垂直 方向の 2 通りとした。水平方向の方向弁別限の測定の際はスピーカア レイを水平に設置し、垂直方向の測定の際は垂直に設置した。基準ス ピーカの位置は、図 2 に示すように、水平角、仰角とも 30 度おきと したが、仰角 90 度の基淮位置における水平方向の变化に関しては、垂 直方向の変化と同じになるため測定していない。被験者は水平方向の 変化に対しては 10 名、垂直方向の変化に対しては6名である。また、 実験中は、頭部者固定寸るとともに、スピーカアレイの焦点と頭部中 心がずれないように、被験者は被験者前方のパイプにアゴを載せるこ ととした。

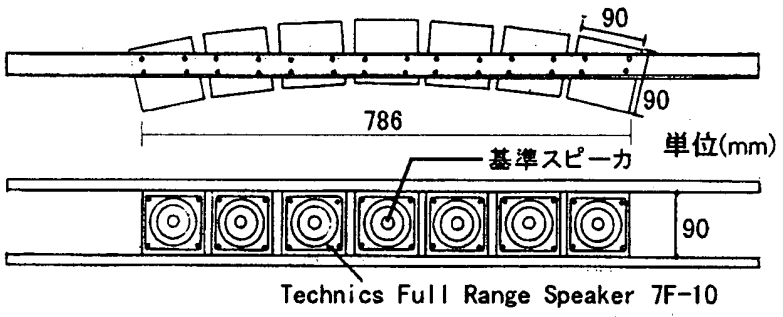

图1実験に用いたスピーカアレイ

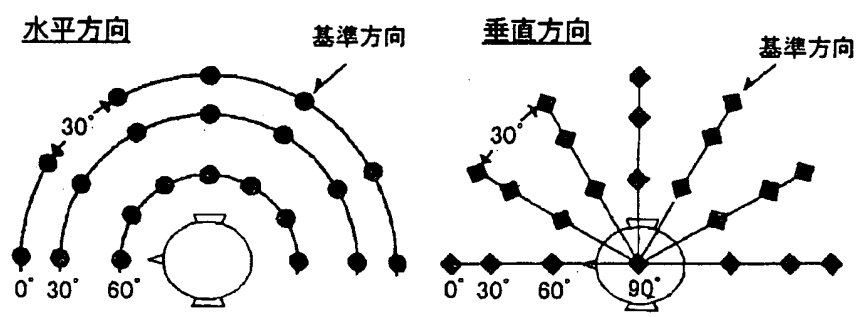

図2 基準スピーカの位置
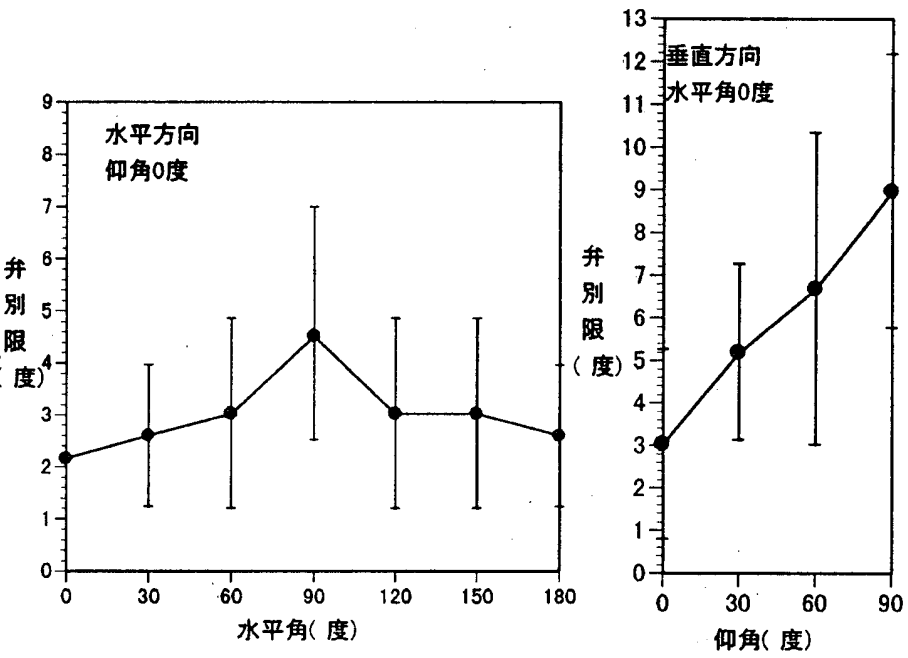

図3実験值および標準偏差
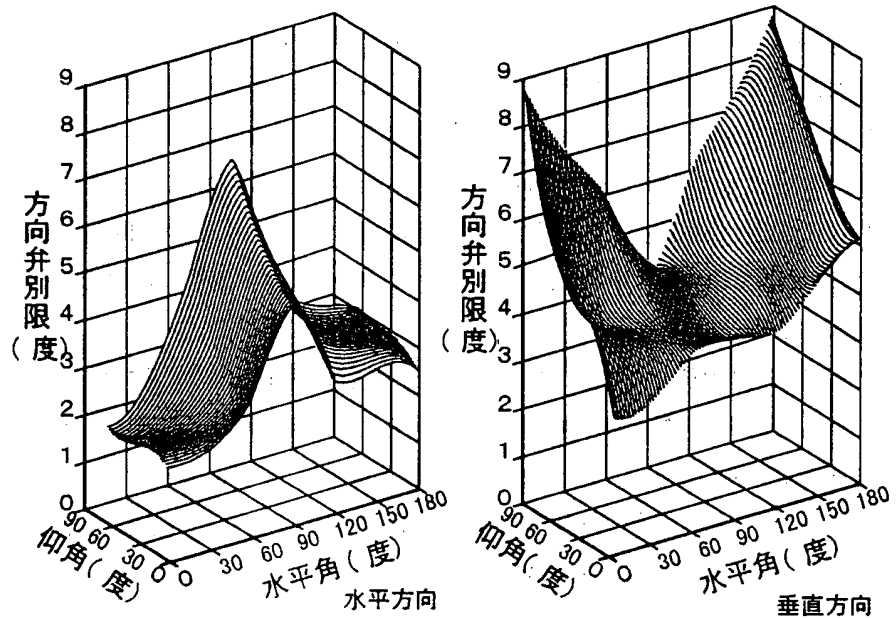

図4 水平および垂直方向の方向弁別限の傾向 
各测定方向について、全ての被験者のデータを単純平均し、方向弁 別限とした。図 3 に水平面、正中面方向における実験結果および各 被験者の弁別限による標淮偏差を示す。

図 4 に実験結果をスプライン補完して得られた全体の傾向を示す。 これを見ると、水平方向の弁別限は前方で最も小さく約 2 度となり、 横方向では大きくなるが、後方になるにしたがい再度小さくなってい る。

垂直方向では、水平角 90 度において仰角による変化は小さいが、そ の他の水平角では仰角が大きくなるほど大きくなる傾向を示してお り、真上では最大の約 9 度となっている。

\section{2 被数音源による到来角度の弁別限}

実音場では、単一の方向から音が到来することはなく、直接音に続 き複数の反射音が時系列上で分離せずに知覚される。このとき音像自 体が拡がりを持って知覚されることが広く知られており、立体角の分 割を複数音源による到来角度の弁別限に基ついて分割すれば、単一音 源の方向弁別限に基づく分割より荒くてもよいことが推測される。そ こで、単一音源による方向弁別限测定結果とあわせて立体角の分割方 法を決定するために、直接音と複数の反射音が同時に存在するとき、 音像の見かけの幅を変化させない反射音の到来角度の幅を、水平面上 の代表方向について測定した。

実験は無響室において行った。図 5 に寒験ブロックダイヤグラム を示す。まず、正面スピーカDから直接音を出力し、左右対称の位置 に設置した一組のスピーカから反射音を出力する。反射音の基準方向 は土45 度 (スピーカ A)および士 135 度 (スピーカB)の 2 パターンと した。直接音スピーカと、基湰方向に設置された一組のスピーカであ る基準スピーカの組み合わせによる音場と、直接音スピーカと基淮ス ピーカから角度を変化させたスピーカとの組み合わせによる音場を一 対として提示し、この一対の音場の比較において变化角度を 5 度ごと に増加、减少させたとき、見かけの音源の幅の変化が判別できるかを 被験者に回答させた。実験は適応法により、被験者の回答が同じ角度 で 3 回程度入れ替わった角度の中間をもって弁別限とした。

試跧音は、無響室録音のモーツァルトの弦楽四重奏曲「ディベル ティメント」第三楽章に、大規模シューボックスホールの一階中央付 近における正四面体頂点法による測定から得られた方向別のパルス列 (エネルギパルス応答)の初期反射音部(直接音より $180 \mathrm{msec}$. まで)を 直接音と左右の基準方向を中心とした 45 度の籁囲内を通過して受音 点に到達してくる反射音に分けてそれぞれ畳み込んで作成した。基準 となる音場と比較する音場の提示時間はともに約 8 秒、音場と音場 との休止時間は約 2 秒、再生レベルは約 $65 \mathrm{~dB}(\mathrm{~A})$ とした。被験者は成 人男女 11 名でる。各被験者の弁別限の単純平均を取り、基準方向 の弁別限とした。

表 1 に測定結果および各被験者の弁別限による標準偏差を、単一 音源による方向弁別限測定結果と合わせて示す。なお、両者とも方向 の違いを判別できない角度の幅として示しているため、単一音源の弁 別限は前項で示した値の倍となっている。表 1 を見ると、基準方向 45 度および 135 度における方向弁別限は、単一音源の約 3 倍になっ ている。複数音源における弁別限の測定は、水平面上の 2 基淮方向の みであったが、本シミュレーション手法においては単一音源による方 向弁別限を全方向に対して 3 倍の割合で执げたものを複数音源の方向 弁別限とみなすこととした。

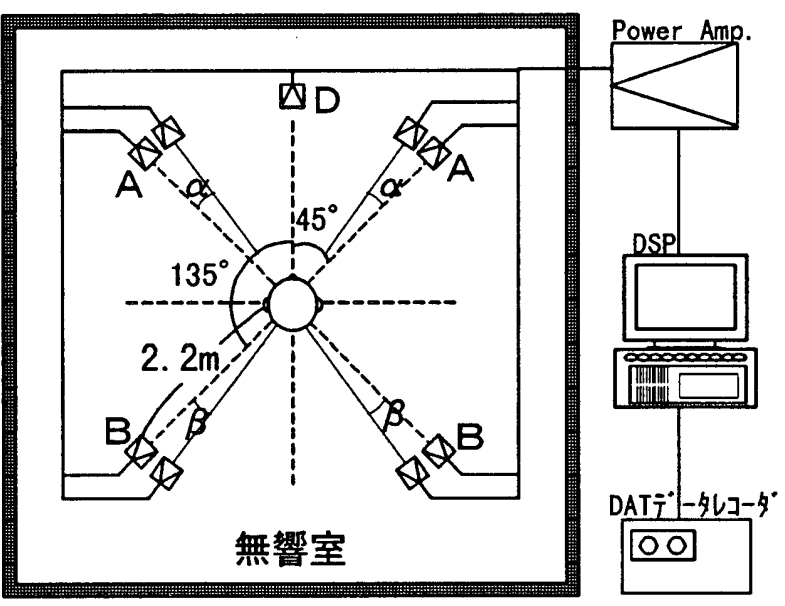

図5 実験ブロックダイヤグラム

表 1 単一音源と複数音源の方向弁別限の比較

\begin{tabular}{|c|c|c|c|}
\hline 測定方向 & 単一音源 & 被数音源 & 標準偏差 \\
\hline $45^{\circ}$ & $5.5^{\circ}$ & $16^{\circ}$ & $2.62^{\circ}$ \\
\hline $135^{\circ}$ & $6^{\circ}$ & $19.8^{\circ}$ & $4.16^{\circ}$ \\
\hline
\end{tabular}

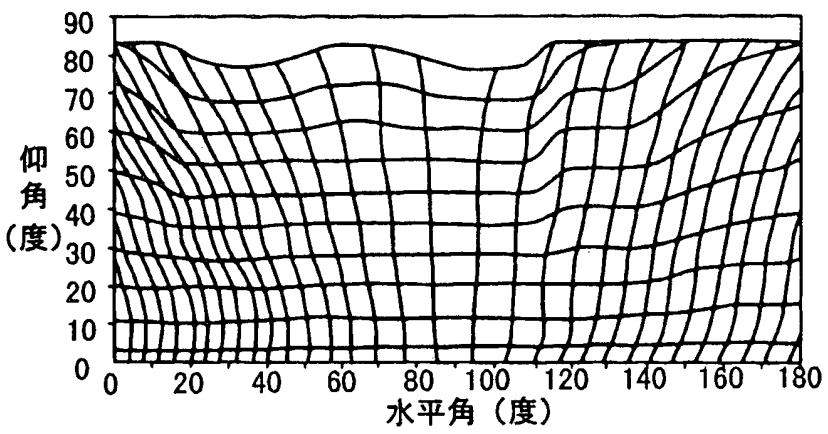

図6 单一音源の方向并別限に基つく立体角の分割

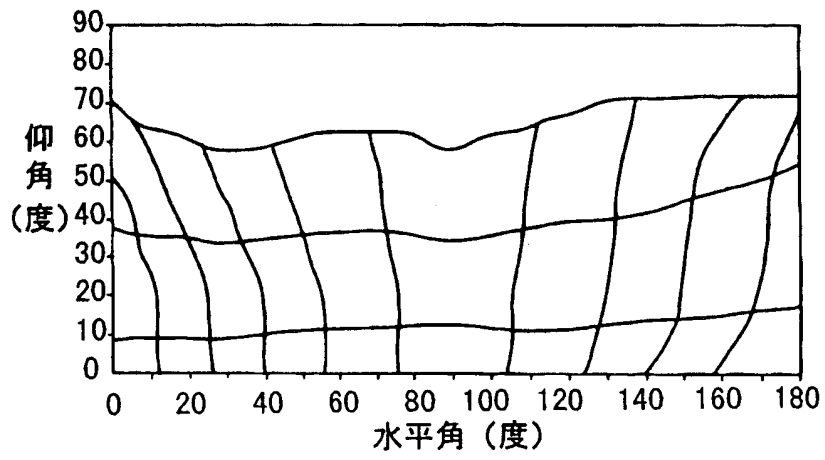

図7複数音源による到来角度弁別限に基づく立体角の分割

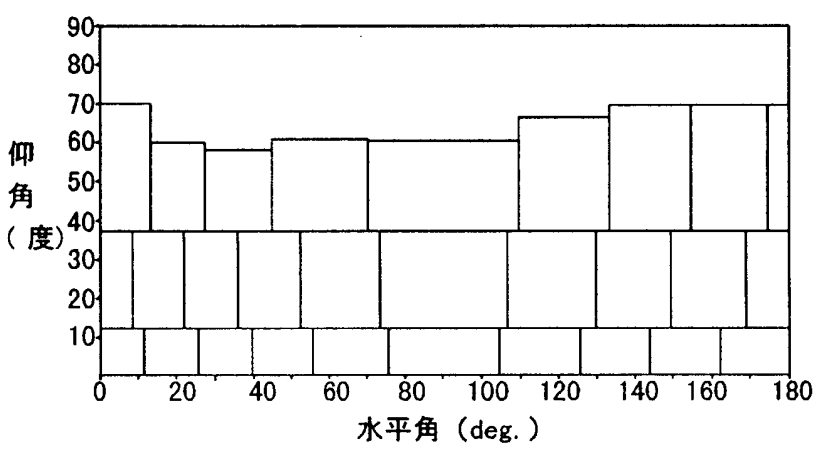

図8単純化した立体角の分割 


\section{3 立体角分割方法}

図 6 に単一音源による方向弁別限の測定結果からの立体角分割の 様子をメルカトル図法により作成したものを示し、これを 3 倍して得 られた複数音源における立体角分割の様子を図 7 に示す。複数音源 における立体角の分割は、単一音源に比へて荒くなり、その境界線は 複雑な曲線を描いている。図 7 の立体角の分割を数值シミュレー ションにそのまま組み込むと、到来した反射音がどの立体角の範囲に 入るかの判定が複雑になり、計算時間の増大につながるため好ましく ない。そこで、各立体角の筙囲を水平角、仰角のみで表現できるよう に単純化した。図 8 に単純化した立体角の分割の様子を示す。得ら れた立体角の分割は水平面より上方のみであるが、コンサートホール のバルコニ席では下方より到来する反射音についても考慮しなければ ならない。そこで、仰角 $-30 〜 0$ 度までは水平面に対して対称として 分割した。

以上のように作成した立体角分割の様子を図 9 に示す。立体角の 分割数は、全体で 106 分割である。また、立体角に対応する頭部伝達 関数は、保有する約 1400 方向の測定結果から、分割した立体角の中 央付近に対応する頭部伝達関数を用いることとし、数值シミュレー ションに組み込んだ。

\section{4 両耳におけるインパルス応答の算出方法}

因 10 に両耳におけるインパルス応答算出方法の概念図を示す。 まず、数值シミュレーションにより、前項で作成した立体角内を通過 して受音点に到達する方向別のインパルス応答を算出する。これに立 体角に対応する左右一対の頭部伝達関数を盢み込むことにより、各立 体角内を通って受聴者の両耳人到達するインパルス応答が得られる。 分割した全立体角について同様にインパルス応答を求め、両耳におけ る時系列上に順次重ね合わせていくことで、音場合成に必要な両耳に おけるインパルス応答を得る。この両耳における左右一対のインパル ス応答に、モノラルのドライソースをそれぞれ畳み込んで試聴用の音 源ソースを作成し、OS S等のバイノーラル再生手法を用いて受聴者 に立体的な音場を提示する。

\section{3. 拡散状態に到達する時間の简易的予㨽方法の検討}

数值シミュレーションから合成した音場を用いて聴感上の検討を加 えるためには、精度良く室内のインパルス応答を予測する必要がある が、精度を得ようとすると計算時間は増大し、また各種の境界条件に 関するデータが十分に得られていない現状では、拡散音成分が主とな る後期では、計算誤差が大きくなる傾向にある。

そのため、筆者らは初期反射音部分に反射音時間構造を考慮した残 響音を付加し、聴感上において実際の残響音と聴感上の差が生じない ような残響音付加手法を検討してきた ${ }^{6}$ 。残響音付加手法の検討の際 には実音場での正四面体頂点法を用いた短時閒指向拡散度測定結果い図 10 を参考に、残響音を付加する直接音からの時間を決めてきたが、数值 シミュレーションによる初期反射音に残響音を付加する場合、設計対 象としたホールにおいて、どの時点で拡散に移行するかを予測する必 要性がある。

3.1 拡散状態に到達したとみなせる時間の簡易的予測手法

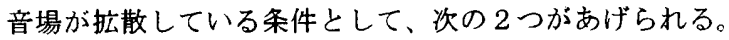

(1) 音のエネルキが室内全体に一様に分布している。

（2）音があらゆる方向に等しい確率で伝搬している。
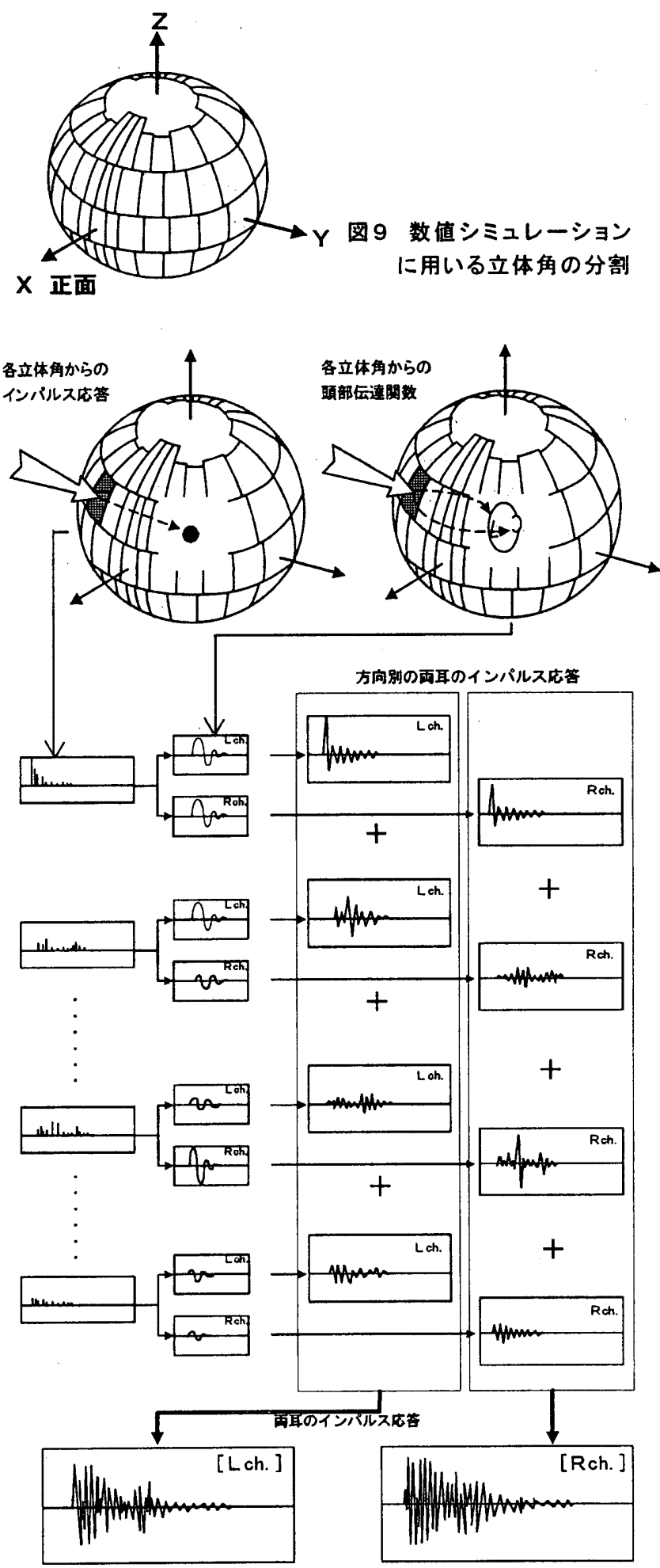

数値シミュレーションからの両耳におけるインパルス店算出

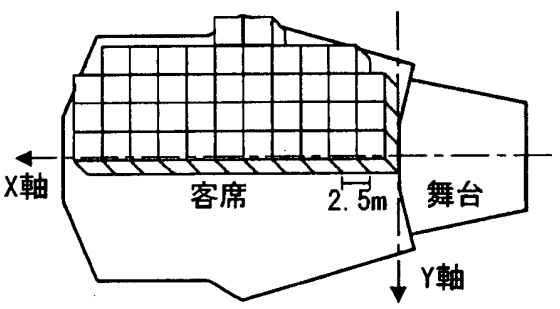

図11キューブ分割方法 
この $2 つ の$ 条件に関し、時間のパラメータを考慮するため、拡散状 態に到達したと見なせる時間の予測には、室内における波面の位置、 進行方向およびエネルギを把握しやすい音線法を用いることとした。 また、波面積分法においても、波面を追跡するためのガイドとして音 線を用いているため、音線法を用いた拡散までの時間の予測ルーチン を波面積分法に組み込めば、数值シミュレーション内部で初期反射音 の計算打ち切り時間が明確にできる。

室内における音のエネルキ分布を検討するため、图 11 に示すよ うにホールの客席部分に一辺 $2.5 \mathrm{~m}$ の立方体 (キューブ)を隙間無く並 ぶように配㯰した。配㯰するキューブが壁面、バルコニ等と重なり、 形状が完全に保たれない時は、その位置のキューブは作成しない。こ のようにして、室内の客席部分に同じ大きさ・体積のキューブを作成 し、舞台上の音源位圈から音線を放射する。音線が壁面で反射する際 は、壁面の $500 \mathrm{~Hz}$ 帯域の残響室法吸音率を音線の持つエネルギに乗じ た分だけ音線のエネルギが減少するとして、波頭面を構成する全音線 の位置とエネルギを追跡することで、時間ごとに各キューブ内に位置 する $500 \mathrm{~Hz}$ 帯域のエネルギを求めた。そして、全キューブ内の標準偏 差を、偏差の最大値で正規化したものを室のエネルキ偏差とした。

音線の伝搬方向について見るために、ある時刻に作成した各キュー ブ内に存在する全方向ベクトルを単位ベクトルとしてベクトル合成 し、 $\mathrm{X}, \mathrm{Y}, \mathrm{Z}$ 軸方向成分に分けてその時間変化を示した。さらに各 キューブ内の全時間の最大值で正規化したベクトル合成值の時間変化 を用いて、各キューブごとに音の伝搬方向がどの程度の時間で均一に 移行するかを検郡した。

エネルギ偏差およびベクトル合成值は、 0 から 1.0 までの值をとり、 最大值に到達した後は抬散するに従い0に近づいていく。エネルキ偏 差の時間変化は、一つの空間に対して一つだけであるが、ベクトル合 成值の時間变化は、作成したキューブの数だけ得られる。そのうち予 測に用いるのはインパルス応答を計算する受音点を含むキュープのみ である。受音点を含むキューブのみを予測に用いるため、空間全体と しての拉散状態に到達する時間の予測ではなく、個々の受音点近傍の 空間についての抬散状態に到達する時間の予測となる。実際のホール においても、室中央とバルコニー下では掂散状態に到達する時間は異 なると考えられ、各受音点に対しそれぞれ拡散にいたる時間を予测す る必要性があると考えられる。

3.2 本手法による残響室における扰散状態に到達する状況の険討 現在得られる最も扗散性のよい室の例として、残響室があげられ る。前述の手法を用いた場合、抗散状態がどの様に表現されるかを検 討するため、残響室を対象に予測計算を試みた。用いた残響室の形状 および計算に用いた音源位固を図 12 に示す。音源の高さは床から $1.5 \mathrm{~m}$ とし、音源から 16 万本の音線を放射し、10 回反射まで追跡し た。作成したキューブは合計 9 個であり、キューブ1〜 5 は床面から 1. $25 \mathrm{~m}$ を中心に、キューブ 6〜9は床面から 3.75m を中心として作成 した。

図 13 に得られたベクトル合成值の時間変化を、音が放射された 時刻を0msec. として示す。これを見ると、キューブ 2 およびキュー ブ 6 は約 $20 \mathrm{msec}$. で大きな変動はなくなり、この時のベクトル合成値 の相対值は約 $0.1 \sim 0.2$ である。なお、 $120 \mathrm{msec}$. 程度から変動が小 さくなり、ベクトル合成值が 0 に近づくのは、音線が 10 回まで反射 し、消㓕していっているためであるが、100msec. 程度までは放射し

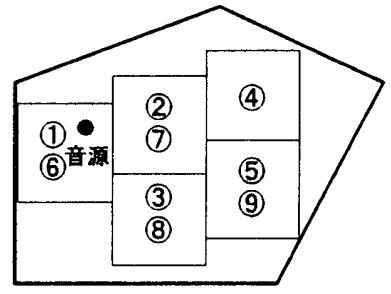

図12 残稫室平面および音源位置
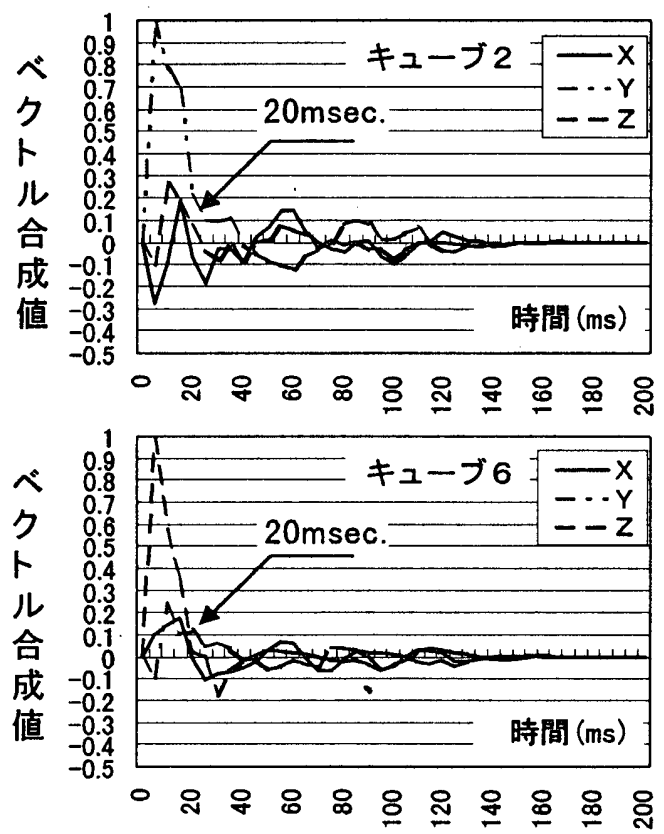

図13 残籍室におけるベクトル合成值の時間变化

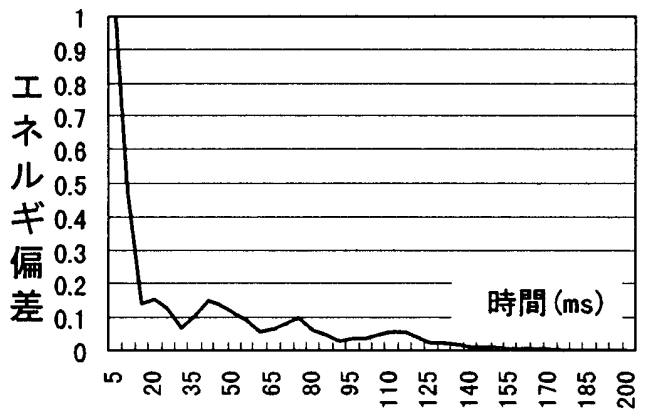

図14 残響室におけるエネルギ扁差の時間変化
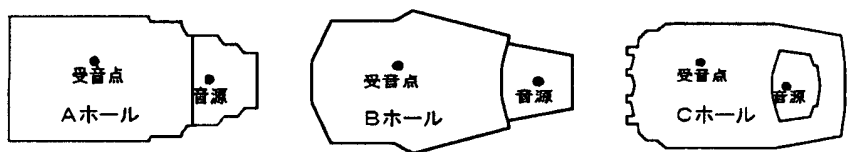

図15 予測に用いたホール

たすへての音線が確保されている時間帯である。図 14 にエネルギ 偏差を示す。ベクトル合成值でそれ以降の時間で大きな変動のなくな る $20 \sim 30 \mathrm{msec}$. について見ると、0.1 前後で安定している。

以上より、本手法において、べクトル合成值による相対值では 0.2 程度以内、エネルギ偏差では相対值 0.1 程度を目安とすることで、拡 散にいたる時間の算出が可能となると考えられる。

\section{3 実測値と予測值の比較}

予測手法の実音場への適用について検討するため、実際のホールで 測定された短時間指向拡散度と本手法による予測值を比較した。 
対象としたホールは、2000人規模の大型のコンサートホールであり、平

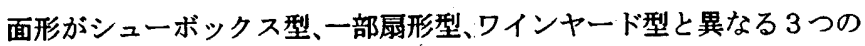
ホールを用いた。図15に用いたA，B，Cホールの平面形および音源・ 受音点位圈を示す。作成したキューブの数は、Aホールで331個、Bホー ルで407個、Cホールでは327個であり、音線放射本数は約 16 万本であ る。ベクトル合成傎の時間変化は、受音点を含むキューブについて検討 した。

3ホールにおける実測の短時間指向拡散度から、拡散状態に到達した とみなされる時間は表 2 のようになる7”。

Aホールの計算結果を図 16 に示す。ベクトル合成について、その変 化幅が 0.2 以内に収まる時間について検討すると $125 \mathrm{msec}$. である。ま た、エネルギ偏差が相対値 0.1 以下となる時間は $180 \mathrm{msec}$. である。表 2 の実測値と比較すると、ベクトル合成ては $55 \mathrm{msec}$. 早く、エネルギ偏 差で同程度となっている。

Bホールの計算結果を図 17 に示す。ベクトル合成は $210 \mathrm{msec}$. で 実測值より $70 \mathrm{msec}$. 早く、エネルキ偏差は $240 \mathrm{msec}$. で $40 \mathrm{msec}$. 早く なっている。しかし、ベクトル合成、エネルギ偏差からの算定値は双 方とも実測の抎散時間と同様に $\mathrm{A} ， \mathrm{C}$ ホールより遅くなっている。

C、ホールの計算結果を図 18 に示す。ベクトル合成は100msec.で 実測より $40 \mathrm{msec}$. 早く、エネルキ偏差は $130 \mathrm{msec}$. と $10 \mathrm{msec}$. 早く なっている。また、ベクトル合成、エネルギ偏差からの算定值は双方 とも実测の拡散時間と同様に $\mathrm{A} ， \mathrm{~B}$ ホールより早くなっている。

本手法において、ベクトル合成およびエネルキ偏差から算定した搪 散にいたる時間には 3 ホールとも、ホール間で実測と同様な差が生じ ている。実測の短時間指向拡散度との比較では、本手法によって算定 した時間のほうが早くなる傾向を示した。そこで、ベクトル合成また

表2 実測の短時間指向拡散度から求めた 拡散に到達する時間

\begin{tabular}{|l|l|}
\hline Aホール & $180 \mathrm{msec}$ \\
\hline Bホール & $280 \mathrm{msec}$. \\
\hline Cホール & $140 \mathrm{msec}$. \\
\hline
\end{tabular}
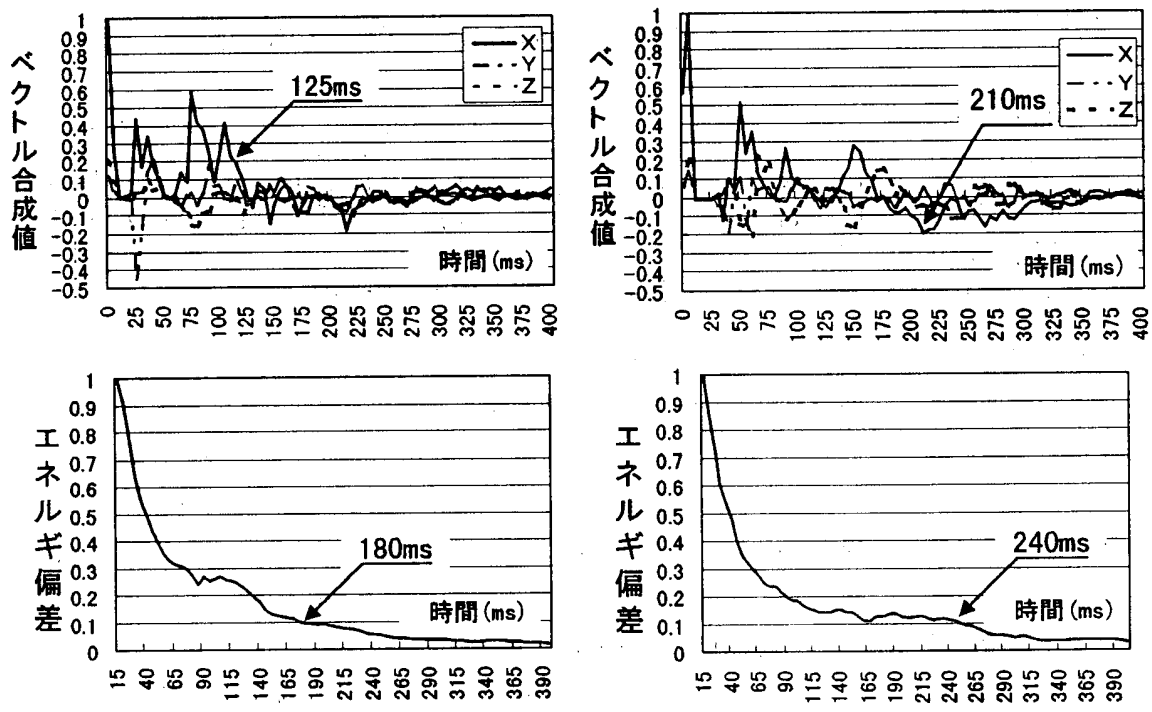

図16 Aホールにおける予测結果
图17 Bホールにおける予測結果

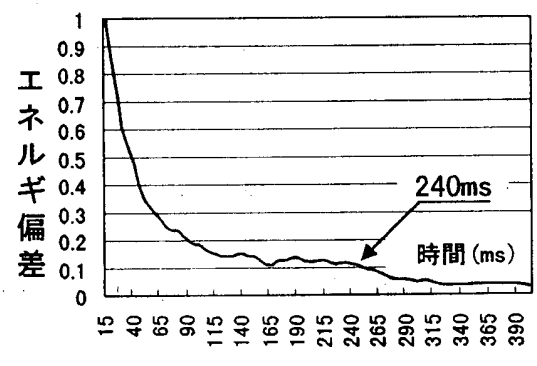

はエネルギ偏差のどちらか遅いほうの值を拡散状態に到達したと見られ る時間として選択し、その時間をもって残警音を付加することとした。 なお、本論文で用いている反射音時間構造を考虑した残響音付加手法 B) は、抬散状態に到達したと見なされる時刻より、50msec. 間の反射音 列に基づいて残響音を作成するため、本手法によって得られた時間より 50msec.だけ長くインパルス応答を計算する必要性がある。

\section{4. 数值シミュレーションからの音堨合成}

音場合成システムは、個々の音響物理指標値からは把握しにくい音 場の特性を受聴者に正確に提示するのが目的であるから、数值シミュ レーションから合成される音場と実際の音場との聴感上の差異が問題 となる。そこで、これまで険討してきた立体角の分割方法、拡散にい たる時間の簡易的予测を含む反射音時間構造を考慮した残響音付加手 法の検討結果を音場合成システムして統合し、数値シミュレーション からの合成音場と実測音場との聴感上の差異について比較聴感実験を 行った。

\section{1 用いた数值シミュレーション手法について}

音場合成に必要なインパルス応答を精度良く予測するため、筆者ら は波動性を考虑した手法である波面積分法5) を用いている。波面積 分法では、長時間インパルス応答による計算時間の増大を抑えるた め、直接音到達時刻から $300 \mathrm{msec}$. 経過ごとに追亦する波面の分割数 を順次半诚する等の実用上の工夫がなされいるが、なお音響設計支援 システムの演算系の中で大きな割合を占めいる。そのため、反射音時 間構造を考虑した残瑤音付加手法6)を用い、全時閒インパルス応答 算出に要する時間の短縮を図る必要があった。

\section{2 数值シミュレーションの初期反射音への残需音付加}

反射音時閒構造を考虑した残響音付加手法 ${ }^{6)}$ は、まず拡散状態に 到達したと見なされる時間から、 $50 \mathrm{msec}$. 間の反射音同士の時間間隔 による度数分布から、残響音全体の反射音時間構造を作成する。つい て、作成した反射音時間構造に基づき頭部伝達関数、周波数特性の時 間変化、またエネルギー堿衰を考慮して左右一対の両耳における残響 音を作成し、初期反射音に付加する。この手法が数值シミュレーショ
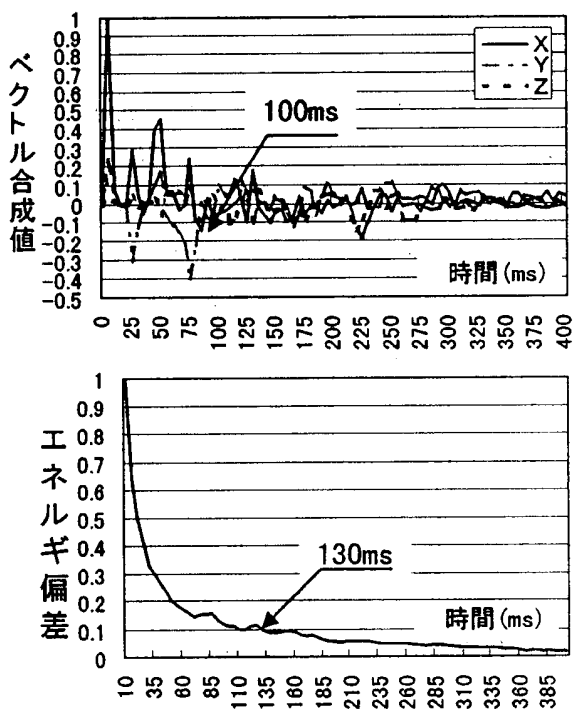

図18Cホールにおける予測結果 
ンに対して、同様に適用できるかを検討した。

図19に波面積分法によるシューボックス型ホールの 1 階中央付 近における無指向性受音のインパルス応答計算結果を示す。また図 20 の上側に、図 19 の計算結果から正四面体頂点法の手法により 変換したエネルギパルス応答を、下侧にエネルギパルス応答から算出 した反射音時間間隔の時間変化を、このホールにおいて拡散状態に到 達したとみなされる $180 \mathrm{msec}$. 以降について示す。図 20 の反射音時 間間隔の時間変化を見ると、波面積分法においては直接音到達時刻か ら 300msec. 経過ごとに追跡する波面の分割数を半堿させているため、 インパルス応答後期になるほど反射音時間間隔が大きくなっている。 反射音時間構造を考㦄した残響音作成手法によれば、拡散状態に到達 したと見なされる時点から、50msec. 間の反射音が得られれば、その 反射音時間間隔の度数分布から残響音全体の反射音時間構造が作成で きる。波面積分法による直接音から $300 \mathrm{msec}$. までは、最も細かい波 面の分割により精度が確保されている時間内であり、この $50 \mathrm{msec}$. 間 の反射音から残響音全体の反射音時間楧造を作成すれば、残響音の反 射音時間棈造を精度よく作成できると考えられる。

図21に当ホールにおいて、抬散状態に到達したと見なされる直接 音到達後 $180 \mathrm{msec}$. から $50 \mathrm{msec}$. 間の反射音により得られた反射音時 間間隔の度数分布を、実測による度数分布と合わせて示す。数值シ ミュレーションからの度数分布は、実測と同様な指数分布を示してお り、反射音時間構造を考慮した残響音を初期反射音に付加する手法を

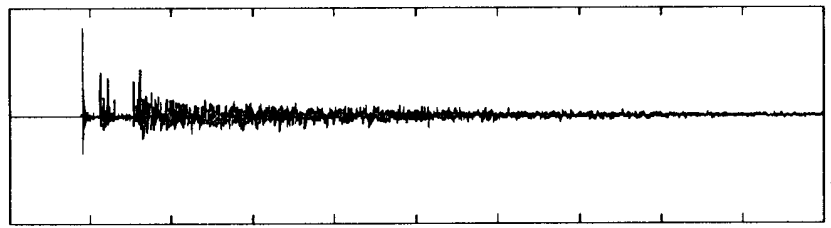

图19 無指向性受音によるインパルス応答計算結果

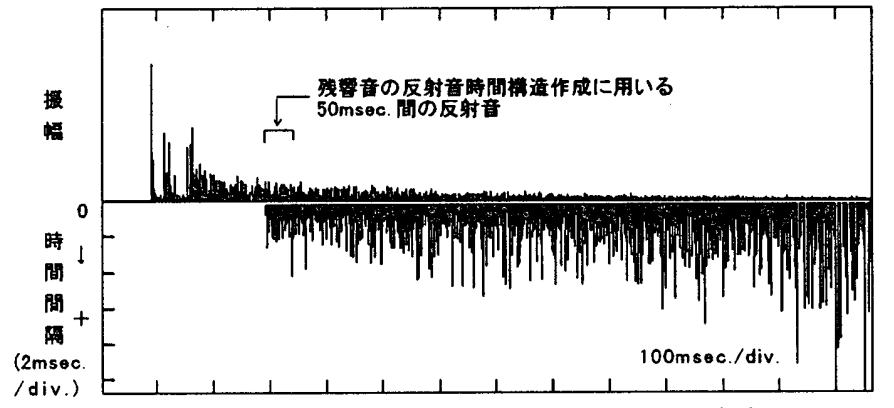

図20 数值シミュレーションからのエネルギパルス 応答および反射音時間間隔
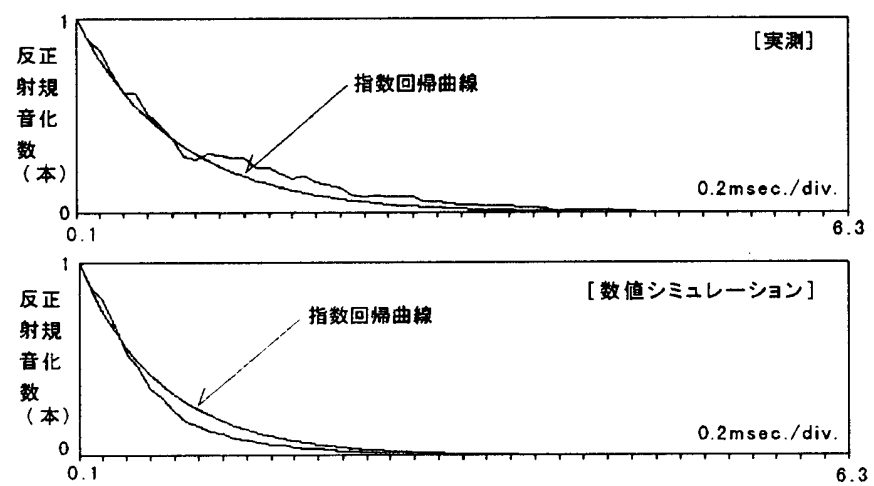

図21 実測と数値シミュレーションとの反射音時間間隔 による度数分布の比較
数値シミュレーションに対しても適用できるものと考えられる。

\section{3 実測音場との比較悖感实験}

数値シミュレーションの初期反射音に反射音時間構造を考虑した残 響音を付加した全時間インパルス応答からの合成音場の聴感上の精度 を検討するため、実湘音場等との比較聴感実験を行った。

図 22 に対象とした A，Dホールの音源、受音点位置を示す。な お、残響音を付加する直接音からの時間は、简易的予测手法による計 算結果から A ホールは180msec. 、Dホールは200msec.である。図 23 に実験に用いたダミーヘッドによる実測のインパルス応答と数 值シミュレーションによる両耳におけるインパルス応答の例として、 $\mathrm{A}$ ホールのバルコニ下における応答を $\mathrm{Lch}$. について示す。数值シ ミュレーションによるインパルス応答には、実測との比較のため、測 定に用いた 12 面体スピーカの特性を異み込んでいる。

表 3 に実験に用いた音場を示す。比較聴感実験に用いる音源とし て、弦楽四重奏曲「ディベルティメント」第三楽章の 10 秒を用いた。 実験は一対比較法により、各受音点ごとに表 3 に示す 4 音場を 2 秒間 の間隔をおいて一対とした 12 対に回答の信頼性をチェックするため
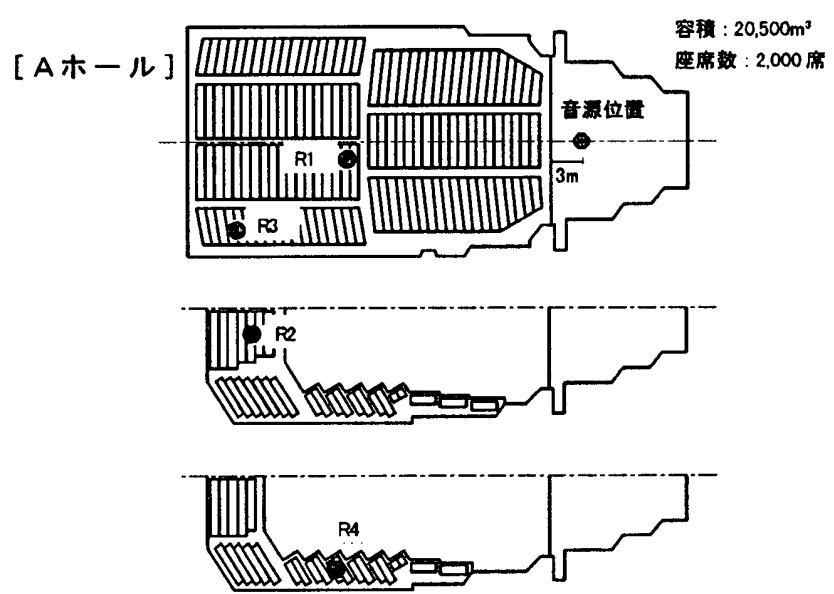

[ロホール]
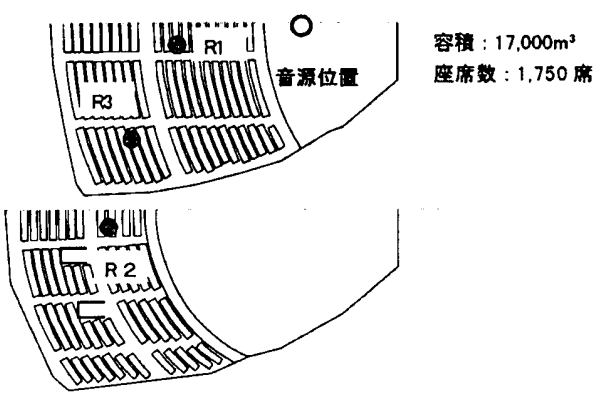

図22 計算に用いたホールおよび受音点位置

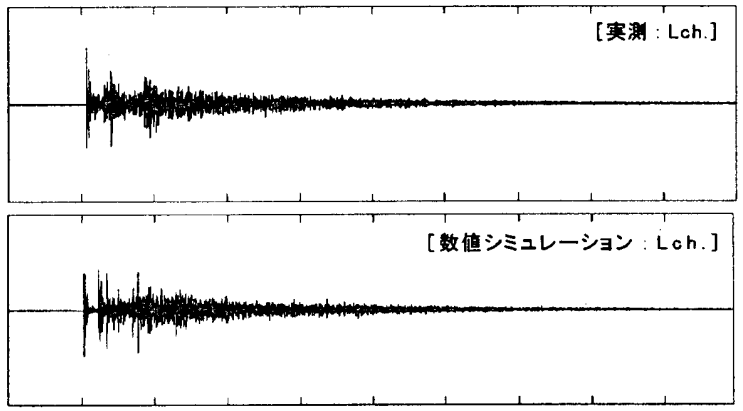

図23実測と数值シミュレーションのインパルス応答例 (R3) 
の同一音場同士の一対を加え、合計 13 対の試験音を作成した。再生 はイヤースピーカを用いたO S S ${ }^{8)}$ により、無響室内で行い、表 4 に示す評価項目について、表 5 に示す 5 段階のカテゴリによって評 価させた。被験者は成人男女 13 名で、再生レベルは約 $65 \mathrm{~dB}(\mathrm{~A})$ とし、 正面方向の頭部伝達関数の補正テータを用いて正面定位の改善を図っ た9!。全実験を通して、同一音場対に対して「明らかに先または後の 音場」と評価した被験者はなく、13名全員の回答結果についてシェッ フェの一対比較法10)により分析した。

図 24 にAホールにおける 4 音場に対する心理尺度構成值を示す。 全体的な傾向を見ると、数值シミュレーションにより全時間インパル 不答を計算した音場 4 は、他の音場とは逆傾向の有意な差が生じて いる。また、実測音場 1 と数値シミュレーションの初期反射音に実測， の残響音を付加した音場 2 は、同様の傾向を示していることから、音 場 4 が他の音場と聴感上の有意な差が生じた原因は主に残響音の違い による見られ、数值シミュレーションによる残響音が聴感上滑らかな 减衰をせず、高周波数成分が強く感じられたためと考えられる。数值 佰 シミュレーションの初期反射音に反射音時間構造を考㦄した残響音を 付加した音場 3 は、音場 4 に比べて実測音場 1 との聴感上の差異が改 善されおり、実測の残響音を付加した音場 2 とも同様な傾向を示して いる。図25にDホールにおける心理尺度構成值を示す。これを見 ると、Dホールにおいても数值シミュレーションからの音場 4 は他の 音場と有意な差が生じているが、音場 2,3 は実測音場 1 と同様な傾 向を示している。

以上の結果から、これまで検討してきた残響音付加手法を数值シ ミュレーションに対して適用することで、数值シミュレーションから の合成音場の聴感上の精度改善が図れることが示された。

\section{5.まとめ}

今後も、数値シミュレーションの精度向上を図るとともに、再生方 法を含む音場合成システムの改良を綂け、数值シミュレーションから成 の合成音場の精度向上を図っていきたい。

\section{謝辞}

本研究に御協力頂いた吉田俊也氏 (元日本大学大学院生、現日本電 気コンストラクション)、佐藤正之氏(元日本大学大学院生、現建材試 験センタ)、佐藤豊成氏 (日本大学大学院生)に感謝の意を表します。

\section{参考文献}

1) たとえば、宫島 徹、田原靖彦、中川 清 : 散乱音シミュレータを導入した室 内音場合成システム、日本音響学会講演論文集、p715-716 (平成 2 年 9 月)

2）イェンス ブラウエルト、森本政之、後藤敏幸編著 : 空間音響, p 5 4-5 5

3）饭田一博、杉浦 聡、森本政之：音場再生に拉ける空間分割の基喏的研究

みかけの音源の幅に基づいた方法一、日本音響学会講演論文集、 $\mathrm{p}$ 833-834（1992）

4）捠田晴夫：基淮的収音・再生を目的とする0rthostereophonic Systemの棬

成、日本音響学会誌、vol39, p337-348(1983)

5）坪井政義：散乱波を考虑した室内音場のインパルス応答予測計算法、日本建 築学会計画系論文集、No. 503, p1-7(1998)

6）渡边充敏、木村 翔、山口 順、平野 滋：0S S を用いた音場合成のためひ 残㗽音付加手法の検討、日本建築学会計画系論文集、No, 503, p9-15(1998)

7）羽入敏樹、木村 翔、橋本 修、坂本吉宏：音場の過渡応答に着目した抾散 性の㛟郡、日本建築学会計画采論文集, No. 471, p11-18(1995)

8）吉田 実、下平美奈子、三浦種敏、浜田晴夫：イヤースピーカを用いた新し いOSS再生方式、AESコンベンション' 91, p138-141(1991)

9）山口 順、木村 翔、渡边充敏、平野 滋：頭部近傍に設置したスビーカに よる音場再生手法の検到、日本建築学会大会学術講演会梗概集、p211-212(1996)

10）芳贺敏郎、橋本茂司：実験データの解析（1）日科技連
表3 比較聴感実験に用いた音場

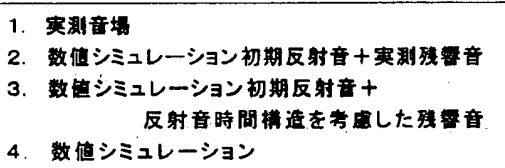

表 4 評価項目

どちちの音塌が

A. 要きが曋かですか?

B、挞がり留がありますか ?

C. 音のはをれがよいですか?

D. 自然な色ですか?

\section{表5 5段階の評定尺度

\begin{tabular}{|c|c|c|c|c|}
\hline $\begin{array}{l}\text { 明らかに } \\
\text { 先の音场 }\end{array}$ & $\begin{array}{c}\text { どちらかと } \\
\text { あうと } \\
\text { 先の昔埸 }\end{array}$ & 周じ & $\begin{array}{c}\text { どちらかと } \\
\text { 苛うと } \\
\text { 摞の音场 }\end{array}$ & $\begin{array}{l}\text { 明らかに } \\
\text { 後の音场 }\end{array}$ \\
\hline
\end{tabular}

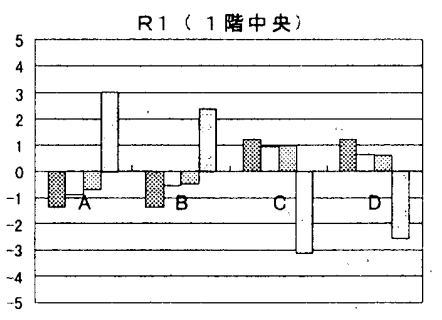

R3 ( 1 階後方壁側)

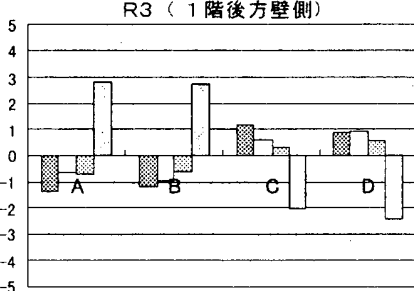

図24Aホールにおける心理尺度構成值

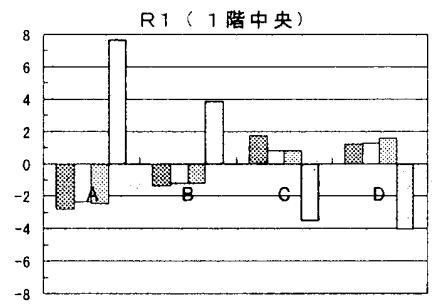

R3 ( 2 階(側方)

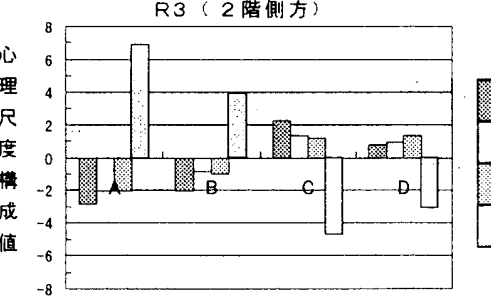

図25Dホールにおける心理尺度構成值 